\title{
AGATOR (Automatic Garbage Collector) as Automatic Garbage Collector Robot Model
}

\author{
Osiany Nurlansa, Dewi Anisa Istiqomah, and Mahendra Astu Sanggha Pawitra, Member, IACSIT
}

\begin{abstract}
This research aims to design and make AGATOR (Automatic Garbage Collector), a rotor robot model as automatic garbage collector to counter accumulation of garbage in the river which has no flow effectively and efficiently. The method of implementation is design and construction. This method includes the identification of needs, analysis of the components required specifically, hardware and software engineering, developing, and testing. The test results obtain data by specification of AGATOR includes IC ATMega16 with 5 Volt voltage and 1,1 mAmpere current, IC Driver with 12 Volt voltage and 1,2 Ampere current, and Limit switch as the controller. Support devices of the robot are mechanical robot, robot control system, sensor system, and actuator robot. The maximum load drives the garbage receptacle until $5 \mathrm{~kg}$. The average speed of robot when take out the garbage is $0,26 \mathrm{~m} / \mathrm{s}$.
\end{abstract}

Index Terms-Automatic, garbage, microcontroller, robot.

\section{INTRODUCTION}

Nowadays, the environment problems arise in many towns in Indonesia. These problems come along by developing activities such as construction of houses, offices, and other business areas. The Environment problems occur due to several reasons; they are the low budget allocation on environment management and public awareness in protecting the environment. The Environment issue which comes up from year to year and still cannot be solved is about garbage and waste from various places dispose into rivers. Those garbages can clog water flow, induce the water become dirty, smelly, and often over flow so then give effect floods.

Minister of Environment, B. Kambuaya, and revealed waste production of 33 cities across Indonesia by the Central Bureau of Statistics records in 2007 reached 132,192 cubic meters per day [1]. Not all of the waste disposed and transported in landfill, for example a lot of garbage that have not been handled properly such as burned and dumped in the river. This phenomenon that causes environment problems. Rivers turn into domestic landfill. B. Kambuaya states 80 percent of river has been polluted by domestic waste [2]. River ecosystem that gets under pressure of high pollution load than other rivers in Java is Ciliwung River. This river is located in Jakarta which passes through many villages which have poor sanitary conditions in general. During the rainy season this river often overflows and causes floods.

Jakarta government makes efforts to overcome trash pollution in the rivers. One of them is to launch issue regulation in Jakarta which prohibits dumping into rivers [3].

Manuscript received February 7, 2014; revised June 17, 2014.

Osiany Nurlansa is with Yogyakarta State University, Indonesia (e-mail: osikura@gmail.com).
Some alternative of wasting management have been are presented among others through the trash bank or recollect bank and reprocess them into handmade items that can make profits. In addition, the Indonesian government also makes effort by the issue of the regulation No. 18 of 2008 on Waste Management along with Government Regulation No. 81 of 2012, mandates the need for a fundamental paradigm shift in the management paradigm that is gathering garbage transporting - processing waste into a convergent on wasting reduction and waste management. Wasting reduction activities means all levels of society include government, business and society conducting restriction of midden. They recycle and reuse garbage which is known as Reduce, Reuse, and Recycle (3R) through intelligent efforts, efficient, and program.

Government's efforts have not been running at maximum. There are many garbages found and clog the stream flows in the river, dumps into the branch of the river, piles up at the doors of water, in ditches, small streams and pose shelter illegal waste, which would damage the surrounding environment. Therefore, we propose the idea to overcome this problem by making AGATOR Design Build (Automatic Garbage Collector) as a Model Robot Automatic Garbage Collector is expected to be the appropriate solution at now. AGATOR's design is for the main motion and paddle's movement obtained from the motor gasoline. This tool will move with paddle when the debit of water on the river is quite a lot, and will utilize the function of the wheel in the river when dry season.

\section{GOAL OF THE RESEARCH}

The purposes of this research are 1) to determine the design of AGATOR and 2) to know the performance of AGATOR automatic garbage collector

\section{Methodology}

The design of garbage collector robot uses engineering method. In sequence, the method is identification of the needs required. Then these needs are analyzed to get specific components. Furthermore, they perform designing hardware and software, manufacturing, and testing.

\section{A. Time and Place of the Research}

This study was held in March until July 2012. This research was conducted in the Department of Informatics Engineering, Engineering Faculty of Yogyakarta State University through designing and manufacturing tool activities, and testing the tool in the swimming pool of 
Yogyakarta State University, rectorate's pool of Yogyakarta State University, and Gadjah Mada University's river which has no flow.

\section{B. Types and Sources of Data}

Sources data used in this paper are divided into two steps, primary data and secondary data. Primary data is data which is taken directly from observations and interviews with Public Works, sluice operating officer, and condition analysis of the river with weak flow or no flow. While the secondary data obtained through reference books, newspapers, and electronic media. Relevant source processed into a descriptive analysis data with conclusions and suggestions.

\section{Research Design}

The approach which is used in this research was designing approach or Research and Development. The procedures used in the development of this tool were those which have developed by experts, including a 10-step model of the development of Borg \& Gall (1983:775) [4] the authors simplified them into 4 steps. In line with the model, the stages taken in developing AGATOR were: 1) analyzing the system needs, 2) designing tools, 3) designing electronic circuits, and 4) preparing and testing.

\section{1) Requirements system analysis}

AGATOR included in the category of rotor mobile robot with navigation system to follow the wall (wall follower). The requirement is obtained as follows

- The main driver of AGATOR is rotor, so it takes mechanical wheel and wheel driver.

- The wheel driver needs to consume power enough in order torque and current are fulfilled, so it takes driver for the wheel.

- A robot in order to be able to move needs an appropriate motion controller.

- In order to be able to move automatically robot needs sensors at the robot navigation system.

From some of the above requirements, then gained some analysis of the need for development tools that will be made, namely:

- The power supply circuit as voltage supplier taken from a lithium polymer battery 22.2 volt $2.2 \mathrm{AH}$ as voltage supplier of the whole system from the robot.

- ATMega8 minimum system circuit. This microcontroller serves as a microcontroller which is used to drive the ultrasonic sensor and sending the measured data from sensor to the microcontroller master.

- ATMega16 minimum circuit as microcontroller master robot controller.

- 2 DC Motor used to drive the robot rotor.

- 2 DC Motor which serves to move the lever if the garbage receptacle is full.

- The necessity of EXPRES PCB software, ISIS, CVAVR as an area for coding and create software that will be included on the IC to drive the robot to run.

- A Downloader robot as medium to enter the CVAVR program to ATMega.

- Adaptor to provide power to ATMega at 5 Volts.

- Blackbox to protect program circuit from the water.

- Capacitor as a current storage.

- IC293 as Driver Motor.

- White cable.

- Rotor as mover forward, backward, and turns left or right.

- Lever of the garbage receptacle and robot frame.

- Photodiode as a sensor for controlling upward motion of the tank when full.

- $\mathrm{ADC}$ as a analog to digital signal converter.

- A set of computer for coding process.

- Data from various parties as the material data used in the preparation of the robot.

- Support equipment such as forceps, scissors, screwdrivers, solder.

- Equipment Design

Designing was a process in manufacturing tools. This step was used to determine the composition of a tool that would be made, so that the result would be as good as authors expected. This step eased the manufacturing process, since the design consisted of making a series of block diagrams and sketches for each block with a specific function and expected equipment specifications.

Here is an outline design of the block diagram of AGATOR:

Each block was connected to form expected tools of system. In order to obtain the expected manufacture, the manufacturing process was divided into two kind of design, hardware and software design.

Most of hardware design included minimum microcontroller system that serves as data processor and input controller from the entire system. Software design included microcontroller programming from data input processing and output would drive relay if garbage has been full (see Fig .1).

\section{2) Designing hardware and software}

- Minimum System ATMega16nd ATMega8

- The selection of ATMega16 microcontroller and circuit system was based on the need of number of input and output devices from an arm robot mover. The most suitable planning to support inputs and outputs was using ATMega16, which owns a 32 pin I / O [5]. Combined with appropriate input and output needs analysis, the control system was needed to make the 32 pin I / O [6].

- ATMega16 microcontroller serves as master microcontroller, which is controlling the entire system from the robot and ATMega8 serves as ultrasonic sensor controller and sending result data from reading sensor to master microcontroller with one way serial communication. Circuit to control DAC (Digital to Analog Converter) that is used to control the speed of DC motor's round.

- 22.2 VDC power supply: Power supply circuit was based on the need of source of DC voltage that is 
lithium polymer battery 22,2 volt $2,2 \mathrm{AH}$ power supply

series for minimum system and sensor objects.

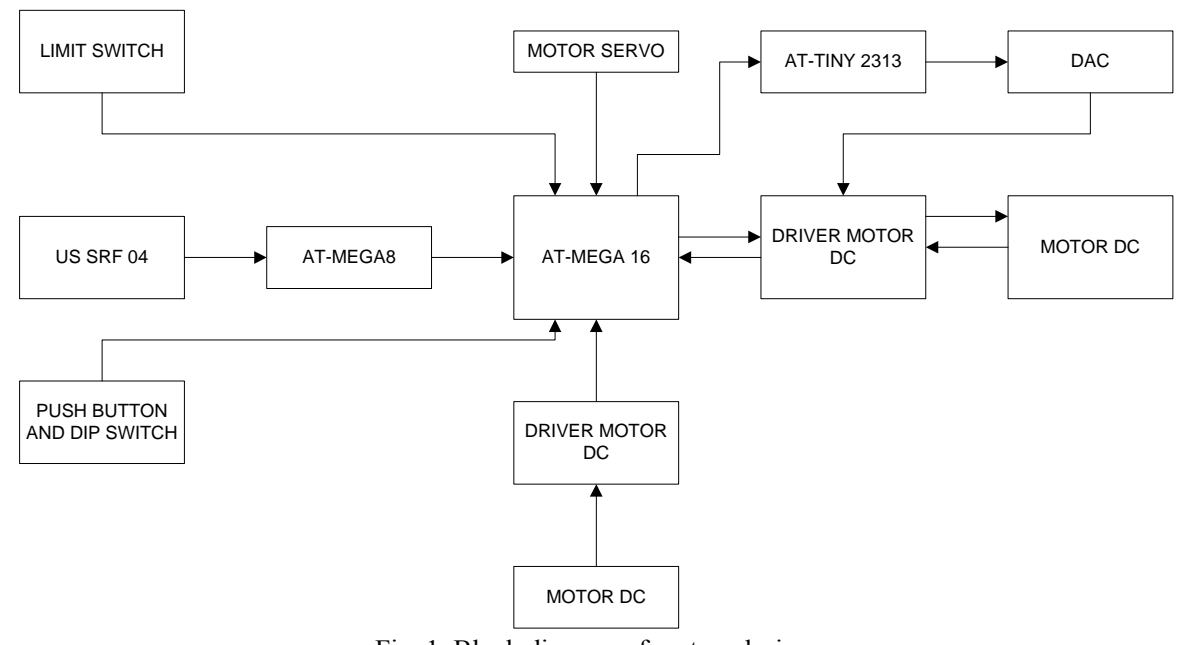

Fig. 1. Block diagram of system design.

- The Author of PCB (Printed Circuit Board): PCB was a board used to put the components needed to make the system. The steps were: 1) drawing Series, 2) printing images on the PCB, 3) dissolving PCB, 4) drilling PCB, and 5) installing the components on the PCB.

- Main Frame of The Robot: Main frame of the robot made from acrylic material with a thickness of $3 \mathrm{~mm}$ and $28 \times 30 \times 38 \mathrm{~cm}$ dimension. At the front part of the robot, there were two limit switches each of the left and right, this was used if in its movement occurred a collision with something, so it could be easier for the robot to come out of the collision by turning the wheel so that one can go back one side on the side which got hit. Using ultrasonic sensor that would detect the position where the garbage was in right, left, front, or rear. Using a 2 wheel right and left aside. The laying of the components and the battery was inserted in the blackbox with security seals that authors made so blackbox was airtight and resistant to water.



Fig. 2. Mechanic of robot.

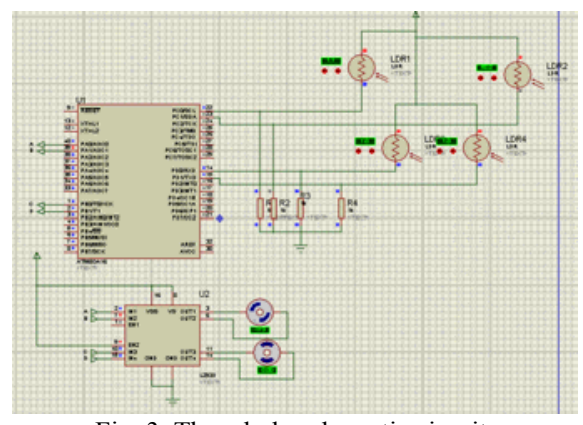

Fig. 3. The whole schematic circuit.
- Series of Box: Once the board was installed in PCB circuit, authors designed the circuit box. The first step was to determine the placement of each block layout of the PCB board that authors created by defining a design tailored to the installation of box sizes to be made. After determining the layout of the circuit, authors conducted a series of installation on the blocks and then it was bolted.

The analysis of ways of Agator working could be described in a flow chart [7] as follows:

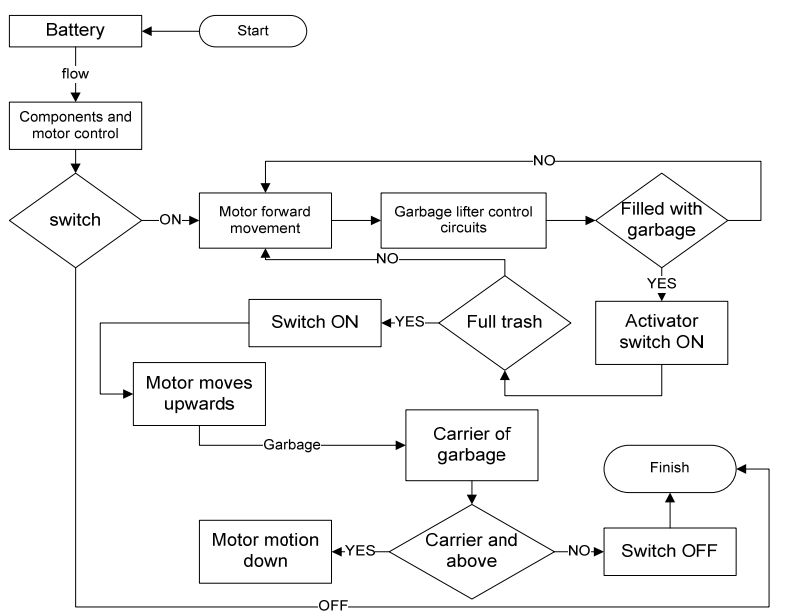

Fig. 4. Flowchart of agator.

The software components in the Automatic Garbage Collector were put in IC microcontroller to determine the data processing and desirable control. Software was designed using CodeVision software AVR [8] which used language C [9] in its programming system. Software design was based on the analysis of the basic working principle of the Automatic Garbage Collector to collect garbage automatically from the river.

- Testing Planning and Data Collecting: Data collecting was conducted to find out the truth and a series of robotic mechanical systems work. Testing was conducted to determine whether the robot had to run according to the expected function. Through data collection, it was expected to be able to compare the 
results with the results of a series of robot design which had been made (see Fig. 2-Fig. 4).

\section{RESUlTS AND DisCUSSION}

\section{A. Tools Testing}

Tools testing were performed in order to determine whether those tool work or not. Testing was performed in the Electronics Engineering Laboratory of Engineering Faculty Yogyakarta State University. Then performed in the field directly at rectorate's pool of Yogyakarta State University to test the function of limit switch and blackbox safety of the water. Further tested in swimming pool of Sport Science Faculty Yogyakarta State University to determine the level of conformity to pick up the garbage that floated on the pool without flow. After there was no obstacle, AGATOR was tested in the real environment, it was in the river of Gadjah Mada University which did not have flow (see Table I- Table VI).

\section{B. Result of Testing and Data Collecting}

\section{1) Ultrasonic sensor testing}

- Ultrasonic sensor was tested by looking at the data from microcontroller process to distance of objects in front of sensor. The advantage of the ultrasonic sensor sense the object(in the shaded area)one can have a better idea of its location and relative size, increasing the accuracy of the sensor [10]. From the test result of ultrasonic sensor, it can be determined that distance of objects measurement to sensor on the water level uses ultrasonic sensor there is little difference by measuring manually with meter receipts.

\begin{tabular}{lll}
\multicolumn{2}{c}{ TABLE I: UltRASONIC SENSOR TESTING } \\
\hline \hline No & Distance Sensor Testing & $\begin{array}{l}\text { Time } \\
\text { (microsecond) }\end{array}$ \\
\hline 1 & $10 \mathrm{~cm}$ & 671,8367 \\
2 & $20 \mathrm{~cm}$ & 1484,9942 \\
3 & $30 \mathrm{~cm}$ & 2263,5423 \\
4 & $40 \mathrm{~cm}$ & 2871,6753 \\
5 & $50 \mathrm{~cm}$ & 3178,9754 \\
6 & $60 \mathrm{~cm}$ & 4419,6459 \\
7 & $70 \mathrm{~cm}$ & 4561,7531 \\
\hline \hline & & \\
& & TABLE II: DAC TESTING \\
\hline \hline No & Data & V out (V) \\
\hline 1 & 0 & 0,01 \\
2 & 10 & 0,17 \\
3 & 20 & 0,32 \\
4 & 30 & 0,54 \\
5 & 40 & 0,73 \\
6 & 50 & 0,92 \\
7 & 60 & 1,25 \\
\hline \hline & \multicolumn{2}{|l}{ TABLE III: MOTOR DAC RoUND SPEED TESTING } \\
\hline \hline No & V in (V) & Speed (Rpm) \\
\hline 1 & 0 & 0 \\
2 & 0,5 & 64,3 \\
3 & 1 & 126,5 \\
4 & 1,5 & 176,8 \\
5 & 2 & 235,7 \\
6 & 2,5 & 312,9 \\
\hline \hline
\end{tabular}

\section{2) Module DAC testing}

Testing was performed by controlling the incoming data so that can be seen from the analog voltage output of DAC.

\section{3) Motor DAC round speed testing}

This testing was performed by giving a different analog voltage input in order to get the speed of a DC motor round.

\section{4) Mechanic testing of garbage collector}

Testing was performed by giving the pool with various types of garbage. Those types are organic garbage (leaves, animals, etc.) with a diameter of different lengths and types of non-organic garbage (plastic, aluminum, etc.) in different sizes.

TABLE IV: MECHANIC TESTING OF ORGANIC GARBAGE COLLECTOR

\begin{tabular}{llll}
\hline \hline No & Diameter of Garbage & Succeed & Failed \\
\hline 1 & $1 \mathrm{~cm}$ & $\checkmark$ & \\
2 & $2 \mathrm{~cm}$ & $\checkmark$ & \\
3 & $3 \mathrm{~cm}$ & $\checkmark$ & \\
4 & $4 \mathrm{~cm}$ & $\checkmark$ & \\
5 & $5 \mathrm{~cm}$ & $\checkmark$ & \\
6 & $6 \mathrm{~cm}$ & $\checkmark$ & \\
7 & $7 \mathrm{~cm}$ & $\checkmark$ & \\
8 & $8 \mathrm{~cm}$ & $\checkmark$ & \\
9 & $9 \mathrm{~cm}$ & $\checkmark$ & \\
10 & $10 \mathrm{~cm}$ & $\checkmark$ & \\
11 & $20 \mathrm{~cm}$ & $\checkmark$ & \\
12 & $30 \mathrm{~cm}$ & $\checkmark$ & \\
13 & $40 \mathrm{~cm}$ & & \\
\hline \hline
\end{tabular}

TABLE V: MeChanic TeSting of NON-ORGANiC GARBAGE

\begin{tabular}{llll}
\multicolumn{4}{c}{ COLLECTOR } \\
\hline \hline No & Diameter of Garbage & Succeed & Failed \\
\hline 1 & $1 \mathrm{~cm}$ & $\checkmark$ & \\
2 & $2 \mathrm{~cm}$ & $\checkmark$ & \\
3 & $3 \mathrm{~cm}$ & $\checkmark$ & \\
4 & $4 \mathrm{~cm}$ & $\checkmark$ & \\
5 & $5 \mathrm{~cm}$ & $\checkmark$ & \\
6 & $6 \mathrm{~cm}$ & $\checkmark$ & \\
7 & $7 \mathrm{~cm}$ & $\checkmark$ & \\
8 & $8 \mathrm{~cm}$ & $\checkmark$ & \\
9 & $9 \mathrm{~cm}$ & $\checkmark$ & $\checkmark$ \\
10 & $10 \mathrm{~cm}$ & $\checkmark$ & $\checkmark$ \\
11 & $20 \mathrm{~cm}$ & $\checkmark$ & \\
12 & $30 \mathrm{~cm}$ & & \\
13 & $40 \mathrm{~cm}$ & & \\
\hline \hline
\end{tabular}

\begin{tabular}{lcc}
\hline \hline \multicolumn{3}{c}{ TABLE VI: TESTING TABLE } \\
\hline \hline Criteria & \multicolumn{2}{c}{ Testing } \\
& I & II \\
\hline Program & OK & OK \\
Right motor & Slow & OK \\
Left motor & OK & OK \\
Right limit switch & OK & OK \\
Left limit switch & OK & OK \\
Photodiode & OK & OK \\
Lifter motor & OK & OK \\
Ultrasonic sensor & OK & OK \\
\hline \hline
\end{tabular}

\section{5) Performance testing of the robot}

AGATOR testing was performed by 2 repetitions. System testing was done in two ways, using: 
- Computer: program was run with the existing simulation facilities in EXPRESS PCB, ISIS, CVAVR.

- AGATOR: program was run using ATMega, IC293, DC Motor, sonsoric sensor, and LDR sensor, Limit Switch and Ultrasonic sensor.

From the test result and data collection then can be analyzed performance of the tool. Fault tolerance can be calculated based on the measurement of large deviations.

Percentage of error at the time of measurement $=$ TEST 1 : $1 / 8 \times 100 \%=12.5 \%$ : TEST 2: $0 / 5 \times 100 \%=0 \%$ Average error $=(12.5 \%+0 \%) / 2=6.25 \%$

Based on the above analysis data of performance, then AGATOR as Automatic Garbage Collector Robot Model is stated to have an error rate of $6.25 \%$ (error). With an error rate $6.25 \%$, the accuracy of this tool is $93.75 \%$. So it is necessary to repair mistakes (error) that occur in the program and tool.

\section{6) Repair and operation agator}

Repair, if possible in terms of the program will be recoding the troubled program, as well as if there is an error of the hardware, to find a solution at this stage. In addition the model of AGATOR will be adjusted to the size and weight of the mass for a balance and stability (see Fig. 5-Fig.6).

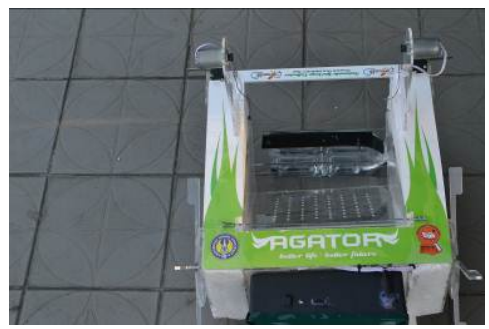

Fig. 5. AGATOR.

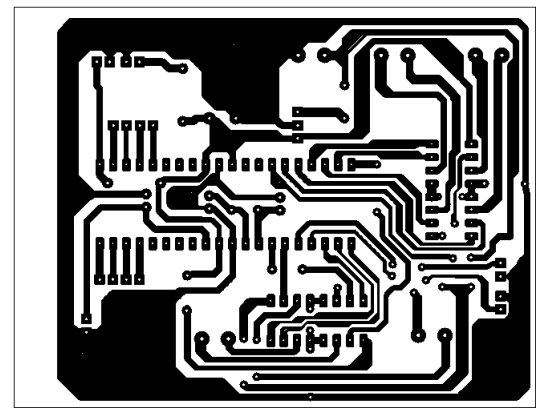

Fig. 6. Encoding the robot program.

\section{CONCLUSION}

Based on the above discussion, it can be concluded:

- AGATOR is designed as robot model of automated garbage collector consists of these steps: requirements analysis, design, manufacturing and testing. This tool consists several parts: ultrasonic sensor, limit switch, LED sensor, toolbox, and circuit which are : a) AVR ATMega16 microcontroller minimum series system, b) AVR ATMega8 microcontroller, and c) power supply circuit.

- AGATOR performance went pretty well, then can be applied automatically to pick up garbage on the waters which do not have flow.

- Based on the above conclusions, authors gives some suggestions as follows:

- For further research will be considered in the use of tools that can be applied in all situations, namely when the water flow is strong, moderate, weak, or no flow.

- Installing RFID as a tool to identify AGATOR's position when working on the river.

- Making an addition system at the garbage receptacle in order to be able to place the garbage directly to river bank when the garbage receptacle has been full.

\section{REFERENCES}

[1] S. Widya. Produksi Sampah Capai 132.192 Meter Kubik Per Hari. [Online]. Available: http://jogja.tribunnews.com/2011/11/09/produksi-sampah-capai-132.1 92-meter-kubik-per-hari.

[2] A. Abdullah and L. H. Menteri. Kerusakan Sampah Masalah Utama Sungai. [Online]. Available: https://id.berita.yahoo.com/menteri-lh-kerusakan-sampah-masalah-uta ma-sungai-072420824.html.

[3] P. D. Jakarta. Perda No. 8 Tahun 2007 Tentang Ketertiban Umum. [Online]. Available: http://www.jakarta.go.id/web/produkhukum/download/346/PERDA_ NO_8_TAHUN_2007_-_Tentang_Ketertiban_Umum.pdf.

[4] W. $\bar{R}$ Borg and M. D. Gall, Educational Research: An Introduction, 4 th edition; London: Longman Inc, 1983.

[5] H. Andrianto, Pemrograman Mikrokontroler AVR Atmega16, menggunakan Bahasa C (codevisionAVR), Bandung: Informatika, 2008.

[6] Anonymous. (October 20, 2012). [Online]. Available: http://www.atmel.com.

[7] B. I. Yatini, Flowchart, Algoritma, dan Pemrograman Menggunakan Bahasa C++ Builder; Yogyakarta: Graha Ilmu, 2010.

[8] L. Wardhana, Belajar Sendiri Mikrokontroler AVR Seri ATMega8535, Yogyakarta: Andi Offset, 2006.

[9] A. Kadir, Pemrograman Dasar Turbo C Untuk IBM PC; Yogyakarta: Andi, 1991.

[10] N. Kelly. A Guide to Ultrasonic Sensor Set Up and Testing Instructions, Limitations, and Sample Applications. [Online]. Available: http://www.egr.msu.edu/classes/ece480/capstone/fall09/group05/docs /ece480_dt5_application_note_nkelly.pdf.

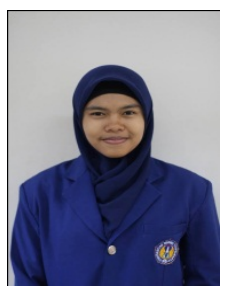

Osiany Nurlansa was born in Cilacap, on 10 July 1992. She is a 7th semester student in informatics engineering education study program, Department of Electronics Engineering Education, Faculty of Engineering at Yogyakarta State University, Indonesia. Her research interests include artificial intelligence and mobile application development.

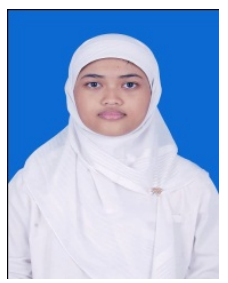

Dewi Anisa Istiqomah was born in Bantul, on 22 January 1992. She is a 7th semester student in informatics engineering education study program, Department of Electronics Engineering Education, Faculty of Engineering at Yogyakarta State University, Indonesia. Her research interest includes design and mobile application development.

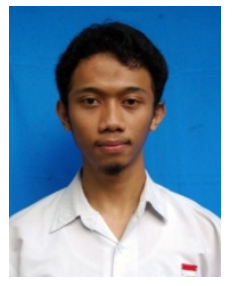

Mahendra Astu Sanggha Pawitra was born in yogyakarta, on 3 March 1993. He is a 5th semester student in informatics engineering education study program, Department of Electronics Engineering Education, Faculty of Engineering at Yogyakarta State University, Indonesia. His research interests include artificial intelligence and mobile application development. 